\title{
Struktur Populasi dan Natural Increase Sapi Potong di Kecamatan Terbanggi Besar Kabupaten Lampung Tengah
}

\section{Population Structure and Natural Increase of Beef Cattle Farming in Terbanggi Besar District Central Lampung Regency}

\author{
A Oktafiani $^{1}$, Y Sukaryana ${ }^{1 *}$, dan S S Kaffi ${ }^{1}$ \\ ${ }^{1}$ Jurusan Peternakan Politeknik Negeri Lampung, \\ Jln. Soekarno Hatta No 10 Rajabasa Bandar Lampung, 35144 \\ *E-mail : yana1962@gmail.com
}

\begin{abstract}
This study aims to examine the population structure, natural increase and profile of beef cattle farms in Terbanggi Besar District, Central Lampung Regency. This research was conducted in the field through survey methods (simple random sampling and snowball sampling) in four villages in Terbanggi Besar District, Central Lampung Regency with descriptive analysis. The number of samples is 742 beef cattle from 95 cattle breeders, the respondents were selected to be interviewed by means of a questionnaire. The variables observed included population structure, birth rates, purchases and immigration, mortality rates, slaughter and sales rates, natural increases in cattle and the profile of beef cattle breeders. The results showed the population structure of bulls and cows has a ratio of 1: 1.48. The natural increase rate is low with a value of $4.59 \%$ for the population and $11.57 \%$ for adult females.
\end{abstract}

Keywords: beef cattle, natural increase, population structure

Diterima: 1 Juni 2021, disetujui 15 Desember 2021

\section{PENDAHULUAN}

Seiring dengan bertambahnya jumlah penduduk dan pertumbuhan ekonomi masyarakat, tingkat pendapatan serta kesejahteraan hidup juga mengalami peningkatan, sehingga merubah kesadaran masyarakat akan pentingnya gizi dan kesehatan, maka permintaan daging yang bersumber dari ternak setiap tahunnya terus meningkat. Ternak sapi merupakan salah satu sumber daya penghasil daging yang baik dan memiliki nilai ekonomi yang tinggi. Daging sangat bermanfaat untuk pemenuhan gizi tubuh berupa protein hewani, tetapi sumber daya ternak masih belum mampu memenuhi tingkat permintaan daging sapi baik dalam mutu maupun jumlah (Direktorat Budidaya Ternak Ruminansia, 2007) Saat ini upaya pemerintah dalam memenuhi permintaan daging khususnya daging sapi sebanyak 30\% masih dipenuhi dengan cara impor daging beku dan bakalan dari Australia (Suhana, 2016) Sehingga jika kondisi tersebut tidak diimbangi dengan peningkatan populasi maka akan terjadi pengurasan ternak sehingga jantan bahkan betina yang produktif pun ikut dipotong.

Struktur populasi perlu diketahui sebagai suatu parameter dalam mengatur sistem perkawinan, manajemen pemeliharaan dan jumlah populasi di peternakan rakyat, dengan demikian dapat diketahui berapa induk betina dan betina muda produktif dengan rasio antara induk betina dan betina muda dengan pejantan (Arif, 2015). Besarnya populasi ternak dipengaruhi oleh berbagai penyebab antara lain: banyaknya pemotongan, kematian, ekspor ternak dan tinggi rendahnya natural increase (Putra, 2017) Selain struktur populasi, natural increase juga sangat dibutuhkan untuk perbaikan produksi. Tujuan perhitungan nilai natural increase (pertambahan populasi secara alami) dilakukan untuk mengetahui naik turunnya populasi 
ternak disuatu wilayah (Tatipikalawan dan Hehanussa, 2006). Terbanggi besar merupakan kecamatan yang berada di Kabupaten Lampung Tengah yang memiliki populasi sapi terbesar di Provinsi Lampung (BPS Lampung Tengah, 2013). Tujuan dari penelitian ini adalah untuk mengkaji struktur populasi, natural increase dan profil peternakan sapi potong sebagai penentuan kebijakan pengembangan sapi potong.

\section{METODE PENELITIAN}

\section{Bahan dan Alat}

Bahan yang digunakan dalam penelitian ini yaitu kuesioner yang digunakan sebagai hasil data dalam penelitian sehingga data dapat dijadikan hasil analisis.

\section{Metode pengumpulan data}

Metode pengumpulan data yang digunakan dalam penelitian ini yaitu dengan cara sebagai berikut:

1) Observasi

Observasi dilakukan dengan mengamati langsung dengan mencatat secara sistematik obyek yang akan diteliti mengenai struktur populasi, natural increase dan profil peternakan sapi potong di Kecamatan Terbanggi Besar.

2) Wawancara

Teknik ini digunakan untuk mengumpulkan data primer dengan wawancara langsung kepada responden yaitu peternak yang ada di Kecamatan Terbanggi Besar.

3) Studi literatur

Studi literatur digunakan untuk menganalisa obyek penelitian secara teoritis terhadap masalah-masalah yang berhubungan dengan penulisan, melalui pustaka berbagai jurnal ilmiah dan skripsi, artikel-artikel yang relevan, serta sumber lain yang mendukung data sekunder.

\section{Metode penelitian}

Metode yang digunakan dalam penelitian ini adalah metode survei. Metode survei yang digunakan adalah metode simple random sampling. Metode ini digunakan untuk menetukan wilayah yang dijadikan lokasi penelitian. Kemudian untuk pengambilan sampel menggunakan metode snowball sampling.

\section{Pengamatan}

Komponen yang diamati pada penelitian ini adalah keadaan umum responden dan sumber daya manusia, struktur populasi, tingkat kelahiran, pembelian dan imigrasi, tingkat kematian, penjualan dan pemotongan, natural increase, dan profil peternakan sapi potong di Kecamatan Terbanggi Besar.

\section{HASIL DAN PEMBAHASAN}

\section{Struktur Populasi Sapi Potong di Kecamatan Terbanggi Besar}

Struktur populasi ternak merupakan pola penyebaran ternak berdasarkan karakter tertentu. Struktur populasi ternak dapat dibedakan atas jenis kelamin dan umur. Adapun struktur populasi sapi potong di Kecamatan Terbanggi Besar dapat dilihat pada Tabel 1.

Struktur populasi merupakan susunan kelompok organisme yang mempunyai spesies sama (takson tertentu) serta hidup atau menempati kawasan tertentu pada waktu tertentu, struktur populasi ini penting diketahui agar peternak dapat mengetahui perkembangan dan keseimbangan populasi ternaknya dimasa yang akan datang (Arif, 2015). Selain itu, dengan mengetahui struktur populasi peternak dapat memperbaiki sistem manajemen ternaknya. Jumlah sampel populasi Sapi Potong pada empat desa di Kecamatan Terbanggi Besar adalah 742 ekor, dengan jenis sapi Sapi Simental (56,46\%), Sapi Limousin (23,85\%), Sapi Peranakan Ongole (17,78\%) dan Sapi Brangus (1,88\%); struktur populasi berdasarkan umur yaitu Dewasa 
Oktafiani et al.. : Struktur Populasi dan Natural Increase Sapi Potong di Kecamatan Terbanggi Besar Kabupaten Lampung Tengah/Peterpan 3 (2): 41-47

64,51\% (jantan 24,79\%, betina 39,62\%), Muda 22,63\% (jantan muda 9,43\%, betina muda 13,20\%), dan pedet $12,79 \%$ (jantan 5,92\% dan betina 6,87\%). Data tersebut menunjukkan populasi sapi jantan lebih rendah dibandingkan dengan sapi betina, sehingga berpotensi untuk dikembangkan dengan cara alami maupun dengan teknologi rekayasa produksi ternak.

Tabel 1. Struktur Populasi Sapi Potong di Kecamatan Terbanggi Besar

\begin{tabular}{|c|c|c|c|c|c|c|c|c|}
\hline \multirow{2}{*}{$\begin{array}{l}\text { Jenis } \\
\text { Sapi }\end{array}$} & \multicolumn{2}{|c|}{ Struktur Populasi } & \multicolumn{4}{|c|}{ Desa } & \multirow{2}{*}{$\begin{array}{l}\text { Jumlah } \\
\text { (ekor) }\end{array}$} & \multirow{2}{*}{$\begin{array}{l}\text { Persentase } \\
\quad(\%)\end{array}$} \\
\hline & Fase & $\begin{array}{c}\text { Jenis } \\
\text { Kelamin }\end{array}$ & $\begin{array}{l}\text { Nambah } \\
\text { Dadi }\end{array}$ & $\begin{array}{l}\text { Karang } \\
\text { Endah }\end{array}$ & $\begin{array}{c}\text { Terbanggi } \\
\text { Besar }\end{array}$ & $\begin{array}{c}\text { Adi } \\
\text { Jaya }\end{array}$ & & \\
\hline \multirow{6}{*}{$\begin{array}{c}\text { Sapi } \\
\text { Simental }\end{array}$} & \multirow[t]{2}{*}{ Anak } & Jantan & 11 & 6 & 5 & 10 & 32 & 7,64 \\
\hline & & Betina & 18 & 4 & 3 & 7 & 32 & 7,64 \\
\hline & Muda & Jantan & 22 & 6 & 1 & 11 & 40 & 9,55 \\
\hline & \multirow{3}{*}{ Dewasa } & Betina & 27 & 11 & 16 & 14 & 68 & 16,23 \\
\hline & & Jantan & 32 & 14 & 14 & 23 & 83 & 19,81 \\
\hline & & Betina & 60 & 36 & 31 & 37 & 164 & 39,14 \\
\hline \multicolumn{3}{|c|}{ Sub Total } & 170 & 77 & 70 & 102 & 419 & 100 \\
\hline \multirow[b]{2}{*}{$\begin{array}{l}\text { Jenis } \\
\text { Sapi }\end{array}$} & \multicolumn{2}{|c|}{ Struktur Populasi } & \multicolumn{4}{|c|}{ Desa } & \multirow{2}{*}{$\begin{array}{l}\text { Jumlah } \\
\text { (ekor) }\end{array}$} & \multirow{2}{*}{$\begin{array}{l}\text { Persentase } \\
\quad(\%)\end{array}$} \\
\hline & Fase & $\begin{array}{c}\text { Jenis } \\
\text { Kelamin }\end{array}$ & $\begin{array}{c}\text { Nambah } \\
\text { Dadi }\end{array}$ & $\begin{array}{l}\text { Karang } \\
\text { Endah }\end{array}$ & $\begin{array}{c}\text { Terbanggi } \\
\text { Besar }\end{array}$ & $\begin{array}{l}\text { Adi } \\
\text { Jaya }\end{array}$ & & \\
\hline \multirow{6}{*}{$\begin{array}{c}\text { Sapi } \\
\text { Limousin }\end{array}$} & \multirow[t]{2}{*}{ Anak } & Jantan & 5 & 1 & 2 & 1 & 9 & 5,08 \\
\hline & & Betina & 5 & 3 & 5 & 2 & 15 & 8,47 \\
\hline & Muda & Jantan & 12 & 4 & 2 & 7 & 25 & 14,12 \\
\hline & \multirow{3}{*}{ Dewasa } & Betina & 12 & 1 & 8 & 0 & 21 & 11,86 \\
\hline & & Jantan & 26 & 1 & 10 & 15 & 52 & 29,38 \\
\hline & & Betina & 22 & 8 & 15 & 10 & 55 & 31,07 \\
\hline \multicolumn{3}{|c|}{ Sub Total } & 82 & 18 & 42 & 35 & 177 & 100 \\
\hline \multirow{2}{*}{$\begin{array}{l}\text { Jenis } \\
\text { Sapi }\end{array}$} & \multicolumn{2}{|c|}{ Struktur Populasi } & \multicolumn{4}{|c|}{ Desa } & \multirow{2}{*}{$\begin{array}{l}\text { Jumlah } \\
\text { (ekor) }\end{array}$} & \multirow{2}{*}{$\begin{array}{c}\text { Persentase } \\
\quad(\%)\end{array}$} \\
\hline & Fase & $\begin{array}{c}\text { Jenis } \\
\text { Kelamin }\end{array}$ & $\begin{array}{c}\text { Nambah } \\
\text { Dadi }\end{array}$ & $\begin{array}{l}\text { Karang } \\
\text { Endah }\end{array}$ & $\begin{array}{l}\text { Terbanggi } \\
\text { Besar }\end{array}$ & $\begin{array}{c}\text { Adi } \\
\text { Jaya }\end{array}$ & & \\
\hline \multirow{6}{*}{ Sapi PO } & \multirow[t]{2}{*}{ Anak } & Jantan & 0 & 1 & 0 & 0 & 1 & 0,76 \\
\hline & & Betina & 0 & 4 & 0 & 0 & 4 & 3,03 \\
\hline & \multirow[t]{2}{*}{ Muda } & Jantan & 1 & 2 & 2 & 0 & 5 & 3,79 \\
\hline & & Betina & 1 & 5 & 0 & 0 & 6 & 4,55 \\
\hline & \multirow[t]{2}{*}{ Dewasa } & Jantan & 15 & 3 & 6 & 25 & 49 & 37,12 \\
\hline & & Betina & 34 & 18 & 9 & 6 & 67 & 50,76 \\
\hline & Total & & 51 & 33 & 17 & 31 & 132 & 100 \\
\hline & Struktur P & pulasi & & & & & & \\
\hline $\begin{array}{l}\text { Jenis } \\
\text { Sapi }\end{array}$ & Fase & $\begin{array}{c}\text { Jenis } \\
\text { Kelamin }\end{array}$ & $\begin{array}{c}\text { Nambah } \\
\text { Dadi }\end{array}$ & $\begin{array}{l}\text { Karang } \\
\text { Endah }\end{array}$ & $\begin{array}{c}\text { Terbanggi } \\
\text { Besar }\end{array}$ & $\begin{array}{c}\text { Adi } \\
\text { Jaya }\end{array}$ & $\begin{array}{l}\text { Jumlah } \\
\text { (ekor) }\end{array}$ & $\begin{array}{l}\text { Persentase } \\
\quad(\%)\end{array}$ \\
\hline & Anak & Jantan & 1 & 0 & 1 & 0 & 2 & 14,29 \\
\hline & & Betina & 0 & 0 & 0 & 0 & 0 & 0,00 \\
\hline Sapi & Muda & Jantan & 0 & 1 & 0 & 0 & 1 & 7,14 \\
\hline Brangus & & Betina & 1 & 0 & 2 & 0 & 3 & 21,43 \\
\hline & Dewasa & Jantan & 0 & 0 & 0 & 0 & 0 & 0,00 \\
\hline & & Betina & 4 & 0 & 3 & 1 & 8 & 57,14 \\
\hline & Sub Total & & 6 & 1 & 6 & 1 & 14 & 100 \\
\hline
\end{tabular}




\section{Tingkat Kelahiran}

Tingkat kelahiran adalah banyaknya jumlah kelahiran yang dialami oleh seekor ternak betina dalam satu tahun. Tingkat kelahiran anak sapi merupakan ukuran yang paling sesuai untuk mengetahui kesuburan ternak. Adapun hasil dari penelitian lapangan terhadap angka kelahiran sapi betina maupun jantan di Kecamatan Terbanggi Besar Kabupaten Lampung Tengah dapat dilihat pada Tabel 2.

Tabel 2 Tingkat Kelahiran Ternak Sapi Potong

\begin{tabular}{lccccc}
\hline \multirow{2}{*}{ Desa } & \multicolumn{2}{c}{ Jenis Kelamin Pedet } & $\begin{array}{c}\text { Jumlah Pedet } \\
\text { (ekor) }\end{array}$ & $\begin{array}{c}\text { Betina Dewasa } \\
\text { (ekor) }\end{array}$ & $\begin{array}{c}\text { Jumlah Populasi Sapi } \\
\text { (ekor) }\end{array}$ \\
\cline { 2 - 4 } Jantan & Betina & & 56 & 120 & 309 \\
Nambah Dadi & 32 & 24 & 29 & 62 & 129 \\
Karang Endah & 18 & 11 & 23 & 58 & 135 \\
Terbanggi Besar & 12 & 11 & 20 & 54 & 169 \\
Adi Jaya & 13 & 7 & 128 & 294 & 742 \\
\hline Total & 75 & 53 & 100 & & \\
\hline Persentase & 58,59 & 41,41 & & & \\
\hline
\end{tabular}

Pada Tabel 2 menunjukkan bahwa angka kelahiran selama satu tahun terakhir adalah 17,25\% (terhadap populasi) dan terhadap betina dewasa sebesar 43, 54\%. Angka tersebut lebih tinggi dibandingkan dengan penelitian Putra (2017) yang melaporkan bahwa tingkat kelahiran di Kecamatan Payakumbuh Timur, Kota Payakumbuh, jumlah anak sapi yang lahir dalam satu tahun terhadap betina dewasa adalah sebesar $22,69 \%$ dan angka kelahiran anak sapi terhadap populasi adalah sebesar 10,03\%. Tabel di atas juga menunjukkan bahwa tingkat kelahiran sapi jantan lebih tinggi dibandingkan kelahiran sapi betina yaitu 1,4:1.

\section{Pembelian dan Imigrasi}

Pembelian dan imigrasi sapi merupakan faktor yang sangat mempengarhi struktur populasi sapi selain tingkat kelahiran karena dapat meningkatkan angka pemasukan ternak di daerah tersebut. Adapun hasil dari penelitian lapang terhadap angka pembelian dan imigrasi sapi di Kecamatan Terbanggi Besar, Kabupaten Lampung Tengah dapat dilihat pada Tabel 3.

Tabel 3 Pembelian dan Imigrasi Ternak Sapi Potong

\begin{tabular}{|c|c|c|c|c|c|}
\hline \multirow{2}{*}{ Desa } & \multicolumn{2}{|c|}{ Pembelian } & \multicolumn{2}{|c|}{ Imigrasi } & \multirow{2}{*}{$\begin{array}{c}\text { Jumlah } \\
\text { (Ekor) }\end{array}$} \\
\hline & Jantan & Betina & Jantan & Betina & \\
\hline Nambah Dadi & 2 & 4 & 0 & 0 & 6 \\
\hline Karang Endah & 0 & 6 & 0 & 0 & 6 \\
\hline Terbanggi Besar & 0 & 0 & 0 & 0 & 0 \\
\hline Adi Jaya & 6 & 2 & 0 & 0 & 8 \\
\hline Total & 8 & 12 & 0 & 0 & 20 \\
\hline Persentase & 1,08 & 1,62 & 0 & 0 & 2,7 \\
\hline
\end{tabular}

Berdasarkan hasil penelitian yang disajikan pada Tabel 9 data pembelian dan imigrasi sapi adalah 20 ekor dari total populasi sapi 742 ekor (2,7\%). Hal ini menunjukkan bahwa hasil penelitian ini lebih rendah dibandingkan dengan hasil penelitian Putra (2017) yang melaporkan bahwa jumlah pembelian sapi di Kecamatan Payakumbuh Timur Kota payakumbuh adalah sebanyak 18 ekor $(5,64 \%)$ serta penelitian Utami (2015) melaporkan bahwa pembelian sapi di Kelurahan Sapaya Kabupaten Gowa sebanyak 13,90\%. Rendahnya angka pembelian di Kecamatan Terbanggi Besar ini karena harga bibit cukup mahal. Sehingga peternak tidak berminat membeli sapi. 


\section{Tingkat Kematian}

Tingkat kematian merupakan salah satu penentu jumlah populasi dari suatu wilayah karena tinggi rendahnya mortalitas atau tingkat kematian akan berpengaruh terhadap kestabilan struktur populasi ternak. Menurut Dania (1992) angka kematian adalah jumlah ternak yang mati pertahun dibagi dengan jumlah dasar populasi dikali $100 \%$. Adapun hasil dari pengamatan lapang pada tingkat kematian sapi berdasarkan penyebab kematian dapat dilihat pada Tabel 4.

Tabel 4 Tingkat Kematian

\begin{tabular}{|c|c|c|c|c|c|c|c|c|c|}
\hline \multirow{3}{*}{ Desa } & \multicolumn{8}{|c|}{ Penyebab Kematian } & \multirow{3}{*}{$\begin{array}{c}\text { Jumlah } \\
\text { (ekor) }\end{array}$} \\
\hline & \multicolumn{2}{|c|}{ Sakit } & \multicolumn{2}{|c|}{ Kecelakaan } & \multicolumn{2}{|c|}{ Keracunan } & \multicolumn{2}{|c|}{ Melahirkan } & \\
\hline & Jantan & Betina & Jantan & Betina & Jantan & Betina & Jantan & Betina & \\
\hline Nambah Dadi & 1 & 1 & 0 & 1 & 0 & 0 & 0 & 1 & 4 \\
\hline Karang Endah & 0 & 0 & 0 & 0 & 0 & 0 & 1 & 1 & 2 \\
\hline Terbanggi Besar & 0 & 0 & 0 & 0 & 0 & 0 & 0 & 2 & 2 \\
\hline Adi Jaya & 1 & 0 & 1 & 0 & 1 & 0 & 0 & 0 & 3 \\
\hline Total & 2 & 1 & 1 & 1 & 1 & 0 & 1 & 4 & 11 \\
\hline Persentase \% & 18,18 & 9,09 & 9,09 & 9,09 & 9,09 & 0 & 9,09 & 36,36 & 100 \\
\hline
\end{tabular}

Dari tabel di atas menunjukkan bahwa persentase kematian sapi terhadap populasi di Desa Nambah Dadi, Karang Endah, Terbanggi Besar dan Adi Jaya Di Kecamatan Terbanggi Besar Kabupaten Lampung Tengah adalah sebesar 1,48\% (11 ekor dari 742 ekor) dan 3,74\% terhadap betina dewasa (11 ekor dari 294 ekor), dengan empat penyebab utama yaitu karena sakit 27,27\%, akibat kecelakaan 18,18\%, keracunan 9,09\% dan akibat melahirkan 45,45\%. Tingkat kematian dengan penyebab setelah melahirkan lebih besar dibandingkan dengan tiga penyebab yang lain. Hal ini karena akibat terjadinya perkawinan pada betina muda dan belum mengalami dewasa kelamin. Persentase kematian sapi betina ialah sebesar $1,35 \%$, angka ini didapat dari jumlah betina yang mati (6 ekor) dibagi dengan jumlah populasi sampel sapi betina (443 ekor) dikali seratus persen.

\section{Pemotongan dan Penjualan}

Salah satu cara yang dilakukan untuk meningkatkan produktivitas ternak sapi yaitu dengan membatasi pemotongan sapi betina yang masih produktif atau berpotensi memiliki reproduksi tinggi. Adapun data hasil penelitian yang didapatkan tentang pemotongan dan penjualan ternak sapi di Kecamatan Terbanggi Besar, Kabupaten Lampung Tengah dapat dilihat pada Tabel 5.

Tabel 5 Pemotongan dan Penjualan

\begin{tabular}{|c|c|c|c|c|c|}
\hline \multirow{3}{*}{ Desa } & \multicolumn{4}{|c|}{ Indikator Pengeluaran } & \multirow{3}{*}{$\begin{array}{c}\text { Jumlah } \\
\text { (ekor) }\end{array}$} \\
\hline & \multicolumn{2}{|c|}{ Dipotong } & \multicolumn{2}{|c|}{ Dijual } & \\
\hline & Jantan & Betina & Jantan & Betina & \\
\hline Nambah Dadi & 1 & 1 & 40 & 18 & 60 \\
\hline Karang Endah & 1 & 1 & 12 & 6 & 20 \\
\hline Terbanggi Besar & 1 & 0 & 6 & 2 & 9 \\
\hline Adi Jaya & 0 & 0 & 9 & 5 & 14 \\
\hline Total & 3 & 2 & 67 & 31 & 103 \\
\hline$\%$ terhadap populasi & 0,40 & 0,27 & 9,02 & 4,17 & 13,90 \\
\hline
\end{tabular}

Tingkat pemotongan ternak sapi yang terjadi di empat desa di Kecamatan Terbanggi Besar, Kabupaten Lampung Tengah sesuai dengan tabel menunjukkan angka yang cukup rendah yaitu 0,67\% dari total populasi di Kecamatan Terbanggi Besar. Hal ini sejalan dengan pendapat Agung et al. (1981), yang 
menyatakan bahwa sebaiknya imbangan jumlah pemotongan dengan populasi tidak melampaui batas toleransi yaitu sebesar $12 \%$. Namun tingkat penjualan keseluruhan sapi di kecamatan tersebut diperoleh angka yang cukup tinggi yaitu sebesar 19,03\% dari sampel populasi di Kecamatan Terbanggi Besar. Tingginya tingkat penjualan disebabkan oleh semakin banyak permintaan konsumen terhadap daging sapi. Menurut Arif (2015) apabila persentase pemotongan melebihi batas toleransi 12\%, maka akan mengganggu suplai sapi potong dan upaya peningkatan populasi sapi potong.

\section{Natural Increase}

Pengelolaan dan penanganan sapi yang baik merupakan faktor penting untuk meningkatkan populasi sapi, terutama dalam pengendalian pengeluaran ternak salah satu nya ialah dengan cara memperhatian petambahan alami ternak (natural increase). Nilai pertambahan alami diperoleh dari selisih antara angka kelahiran dan pemasukan dengan angka kematian dan angka pengeluaran. Dari nilai pertambahan alami ini, pertambahan populasi ternak dalam satu periode dari suatu wilayah dapat diketahui. Adapun hasil penelitian tentang natural increase sapi potong yang ada di Kecamatan Terbanggi Besar, Kabupaten Lampung Tengah dapat dilihat pada Tabel 6.

Tabel 6 Natural Increase sapi potong di Kecamatan Terbanggi Besar

\begin{tabular}{lrr}
\hline Kelompok & $\begin{array}{r}\text { Terhadap Populasi } \\
(\%)\end{array}$ & $\begin{array}{c}\text { Terhadap Betina Dewasa } \\
(\%)\end{array}$ \\
\hline Persentase Angka Pemasukan Sapi (\%) & 17,27 & 43,54 \\
Kelahiran Sapi & 2,70 & 6,80 \\
Pembelian Sapi & 0 & 0 \\
Imigrasi Sapi & 1,48 & 3,74 \\
Presentase Angka Pengurangan Sapi (\%) & 0,67 & 1,7 \\
Kematian Sapi & 13,23 & 33,33 \\
Pemotongan Sapi & 4,59 & 11,57 \\
Penjualan Sapi & & \\
\hline Natural Increase (Pertambahan Alami) & & \\
\hline
\end{tabular}

Tabel 6 menunjukkan bahwa natural increase pada sapi potong di Kecamatan Terbanggi Besar tergolong rendah. Sumadi (2001) menyatakan bahwa standarisasi nilai natural increase berkisar antara 0 sampai $50 \%$ tergolong rendah, $>50 \%$ sampai $80 \%$ tergolong sedang dan di atas $80 \%$ tergolong tinggi. Peternak menyatakan bahwa jarak kelahiran pedet yang satu dengan berikutnya (calving interval) kadangkala lebih dari 12 bulan sehingga seekor induk melahirkan pedetnya dengan interval 2-3 tahun, kejadian ini akan menyebabkan panen pedet menjadi lambat dan mengurangi populasi ternak. Hal ini karena sebagian besar peternak melakukan pemeliharan ternak sapi hanya sebagai usaha sampingan dari usaha pertanian, sehingga diperlukan pengkajian lebih lanjut penyebab dari rendahnya nilai natural increase tersebut.

Nilai Natural Increase yang tinggi didapatkan dari ketersediaan sapi betina produktif yang memadai, diimbangi dengan tingkat kelahiran yang tinggi, dan rendahnya tingkat kematian. Upaya yang dapat dilakukan untuk meningkatkan nilai Natural Increase dapat juga dilakukan dengan cara mengatur sistem perkawinan, sistem penyapihan pada anak sapi, sistem pemeliharaan, sistem pemberian pakan, dan sistem penanganan kesehatan

\section{KESIMPULAN}

Berdasarkan hasil penelitian sapi potong di Kecamatan Terbanggi Besar Kabupaten Lampung Tengah diperoleh data: struktur populasi sapi jantan dan sapi betina memiliki perbandingan 1:1,48. Angka natural increase rendah yaitu 4,59\% terhadap populasi dan $11,57 \%$ terhadap betina dewasa. 
Oktafiani et al.. : Struktur Populasi dan Natural Increase Sapi Potong di Kecamatan Terbanggi Besar Kabupaten Lampung Tengah/Peterpan 3 (2): 41-47

\section{DAFTAR PUSTAKA}

Abidin, Z. 2002. Kiat Mengatasi Permasalahan Praktis Penggemukan Sapi PO. Agromedia Pustaka. Jakarta.

Agung K., Djojowidagdo, S., Arito dan Sunardi. 1981. Inventarisasi Polusi Supply Ternak Potong. Kerjasama Dinas Peternakan Daerah Tingkat I Jawa Tengah dengan Fakultas Peternakan Universitas Gajah Mada Yogyakarta.

Arif, A. N. 2015. Kajian Struktur Populasi dan Upaya Perbaikan Produksi Ternak Sapi Potong di Kecamatan Libureng Kabupaten Bone. Skripsi. Fakultas Peternakan.Universitas Hassanudin, Makassar. http://repository.unhas.ac.id. [diakses pada tanggal 03/06/2019].

BPS Lampung Tengah. 2013. Populasi Ruminansia di Lampung Tengah. Badan Pusat Statistik Kabupaten Lampung Tengah, Lampung.

Dania, I.B., H. Poerwoto., R. A. Suhardiani., dan T. Hidjaz. 2013. Bahan Ajar Manajemen Ternak Potong dan Kerja. Fakultas Peternakan Universitas Mataram. Mataram.

Direktorat Budidaya Ternak Ruminansia. 2007. Percepatan Pencapaian Swasembada Daging Sapi Tahun 2010. Jakarta.

Putra, E. Y. 2017. Struktur dan Dinamika Populasi Ternak Sapi Potong di Kecamatan Payakumbuh Timur Kota Payakumbuh. Skripsi. Fakultas Peternakan Universitas Andalas. Payakumbuh. http://scholar.unand.ac.id [diakses pada tanggal 05/06/2019].

Suhana, N. 2016. Struktur Populasi dan Natural Increase di Kabupaten Lombok Utara. Fakultas Peternakan. Skripsi. Universitas Mataram. Mataram.

Sumadi. 2001. Estimasi Dinamika Populasi dan Out Put kambing Peranakan Ettawah di Kabupaten Kulon Progo. Buletin Peternakan 25(4):161-171.

Tatipikalawan, J. M. dan Hehanussa, S. C. 2006. Estimasi Natural Increase Kambing Lokal di Pulau Kisar Kabupaten Maluku Tenggara Barat. Jurnal Agroforestri 1(3): 65-69.

Utami, E. U. 2015. Struktur Populasi Sapi Bali di Peternakan Rakyat Kelurahan Sapaya Kabupaten Gowa. Skripsi. Fakultas Peternakan. Universitas Hasanuddin. Makassar. 